have used French pitch, and English composers our high pitch. The first and last may compromise with the second, but are incompatible with each other. To sing Handel in modern English pitch is to unduly strain voices and spoil the effect originally intended. But we subm:t to it even in Handel festivals. There is a greater difficulty in altering pitch in England than on the Continent. We have no subsidised Conservatoires or theatres to which we can say: "Use this standard of pitch, or go without subsidy." Even regimental bands are not supplied at the expense of the State. A new set of instruments is very costly, and more than that, it is long before makers learn how to manufacture correctly to a new pitch. The question is therefore beset with difficulties. But the solution is certainly not to be found in the arithmetic of $\mathrm{M}$. Soret.

\section{THE SCIENCE AND ART MUSEUM, EDINBURGH}

WE understand that Col. Murdoch Smith has been appointed by the Lords of the Committee of Council on Education to the Directorship of this Museum, in succession to the late Prof. Archer. As Lieut. Smith he was associated with Prof. Newton in the discoveries at Helicarnassus, and, subsequently, with Commander Pacher, R.N., undertook the explorations in the Cyrenaica which resulted in the acquisition by the nation of the valuable collection of sculptures now in the British Museum. Latterly, Col. Smith, while employed at Teheran, has acquired for the South Kensington Museum the large and valuable collection of Persian art and manufactures which is so well known there. We believe Col. Smith obtained his first Commission in the Royal Engineers direct from a Scottish University, and is one of the very few officers in that Corps who did not pass through the Royal Military Academy at Woolwich or Addiscombe.

\section{NOTES}

WE take the following from the Times:-The following is the list of selected candidates recommended by the Council of the Royal Society for the election to the Fellowship :-A. W. Baird, Major R.E., P. Herbert Carpenter, D.Sc., Sir Andrew Clark, M.D., Mr. A. A: Common, F.R.A.S., E. W. Creak, StaffCommander, R.N., Prof. E. Divers, H. Hicks, M.D., W. M. Hicks, M.A., F. R. Japp, Ph.D., A. M. Marshall, M.D., Prof. H. N. Martin, D.Sc., C. O'Sullivan, Prof. J. Perry, Prof. Sydney Ringer, and Sidney H. Vines, D.Sc.

OF the fifteen candidates who have thus been selected no less than five are Cambridge men. Mr. W. M. Hicks was bracketed seventh wrangler in the Mathematical Tripos of 1873 . Prof. H. N. Martin, Prof. Milnes Marshall, and Dr. Vines were the seniors in the Natural Science Triposes of 1873,1874 , and 1875 respectively, while Dr. Herbert Carpenter obtained a First Class in the Tripos of $\mathbf{1 8 7 4}$, together with Mr.J. N. Langley, who was elected to the Royal Society in 1883 . The name of the late Prof. F. M. Balfour follows that of Dr. Martin in the Tripos list of 1873 ; while the late Prof. A. B. Garrod was senior in $187 \mathrm{I}$, and the Tripos list of 1870 contains the names of Francis Darwin and E. J. Romanes. The Natural Science Triposes from 1870 to 1875 , inclusive, have thus furnished no less than nine Fellows of the Royal Society, either actual or elect. The names of seven more occur in the Mathematical Tripos lists from 187 I to 1880 inclusive, viz. : J. Hopkinson (I87I), J. W. L. Glaisher (187r), H. Lamb (I872), A. B. Kempe (1872), W. M. Hicks (1873), Rr. T. Glazebrook (1876), and J. J. Thomson (1880). To these may be added the name of Dr. W. H. Gaskell, who obtained mathematical honours in
I869, but has since devoted himself to physiology. All who know Cambridge will recognise how largely these results are due to the influence and example of the late Prof. Clerk Maxwell and of Prof. Michael Foster respectively.

WE are informed that Dr. Frankland, F.R.S., has intimated his intention to resign the Professorship in Chemistry in the Normal School of Science and Royal School of Mines at the end of the current session. Aiplications for the post should be addressed to the Secretary, Science and Art Department.

THE Fifty fifth Annual Meeting of the British Association will commence on Wednesday, September 9, I885, at Aberdeen. The President-Elect is the Right Hon. Sir Lyon Playfair, K.C.B., M.P., Ph.D., LL.D., F.R.S. L. \& E., F.C.S., who will take the place of Lord Rayleigh. The Vice-Presidents are His Grace the Duke of Richmond and Gordon, K.G., Chancellor of the University of Aberdeen, the Right Hon. the Earl of Aberdeen, LL.D., Lord-Lieutenant of Aberdeenshire, the Right Hon, the Earl of Crawford and Balcarres, F.R.S., James Matthews, Lord Provost of the City of Aberdeen, Prof. Sir William Thomson, F.R.S., Alexander Bain, M.A., LL.D., Rector of the University of Aberdeen, the Very Rev. Principal Pirie, D.D., Vice-Chancellor of the University of Aberdeen, Prof. W. H. Flower, F.R.S., Pres.Z.S., Director of the Natural History Museum. General Treasurer : Prof. A. W. Williamson, F.R.S., University College, London, W.C. General Secretaries: Capt. Douglas Galton, C.B., F.R.S., A. G. Vernon Harcourt, F.R.S. Secretary: Prof. T. G. Bonney, F.R.S. Local Secretaries for the mecting at Aberdeen: J. W. Crombie, M.A., Angus Fraser, M.A., M.D , Prof. G. Pirie, M.A. Local Treasurers for the Meeting at Aberdeen: John Findlater, Robert Lumsden. The Sectional Officers are as follows:-A. Mathematical and Physical Science. President: Prof. G. Chrystal, M.A., F.R.S.E. Vice-Presidents : Prof. C. Niven, F.R.S., Prof. A. Schuster, F.R.S. Secretaries : R. E. Baynes, M.A., R. T. Glazebrook, F.R.S., Prof. W. M. Hicks, M.A. (Recorder), Prof. W. Ingram, M.A. B. Chemical Science. President : Prof. H. E. Armstrong, F.R.S. Vice-Presidents: Prof. A. Crum Brown, F.R.S., Prof. H. McLeod, F.R.S. Secretaries: Prof. P. Phillips Bedson, D.Sc., F.C.S. (Recorder), H. B. Dixon, M.A., F.C.S., H. Forster Morley, D.Sc., F.C.S., W. J. Simpson, M.D. C. Geology. President: Prof. J. W. Judd, F.R.S., Sec.G.S. Vice-Presidents: John Evans, Treas.R.S., Prof. W. C. Williamson, F.R.S. Secretaries: C. E. De Rance, F.G.S., J. Horne, F.R.S.E., J. J. H. Teall, M.A., F.G.S., W. Topley, F.G.S. (Recorder). D. Biology. President: Prof. W. C. McIntosh, F.R.S. Vice-Presidents : Prof. I. Bayley Balfour, F.R.S., Prof. J. S. Burdon Sanderson, F.R.S. Secretaries: W. Heape, J. Duncan Matthews, F.R.S.E., Howard Saunders, F.L.S., F.Z.S. (Recorder), H. Marshall Ward, M.A. E. Geography. President : Lieut.-General J. T. Walker, C.B., R.E. F.R.S., F.R.G.S. Vice Presidents : Prof. James Donaldson, F.R.S.E., John Rae, M.D., F.R.S. Secretaries : J. S. Keltie, F.R.G.S., J. S. O'Halloran, F.R.G.S., E. G. Ravenstein, F.R.G.S. (Recorder), Rev. G. A. Smith. F. Economic Science and Statistics. President: Prof, Henry Sidgwick, M.A., Litt.D. Vice-Presidents : Prof. R. Adamson, M.A., LL.D., Sir Rawson W. Rawson, K.C.M.G., C.B., Pres.S.S. Secretaries : Rev. W. Cunningham, D.Sc., F.S.S., Prof. H. S. Foxwell, F.S.S. (Recorder), C. McCombie, M.A., J. F. Moss, F.R.G.S. G. Mechanical Science. President : Benjamin Baker, M.Inst.C.E. Vice-Presidents : Prof. W. C. Unwin, M.Inst.C.E., Prof. H. C. Fleeming Jeukin, F.R.S., M.Inst.C.E. Secretaries : A. T. Atchison, M.A., M.Inst.C.E. (Recorder), F. G. Ogilvie, M.A., E. Rigg, M.A., H. T. Wood, M.A. H. Anthropology. President : Francis Galton, F.R.S., President of the Anthropological Institute. Vice-Presidents 